\title{
Influence of Manila clam aquaculture on rates and partitioning of organic carbon oxidation in sediment of Keunso Bay, Yellow Sea
}

\author{
Sung-Han Kim ${ }^{1,3}$, Sung-Uk An ${ }^{1}$, Won-Chan Lee ${ }^{2}$, Jae Seong Lee ${ }^{3}$, Jung-Ho Hyun ${ }^{1, *}$ \\ ${ }^{1}$ Department of Marine Science and Convergence Engineering, Hanyang University, 55 Hanyangdaehak-ro, Sangnok-gu, \\ Ansan, Gyeonggi-do 15588, Republic of Korea \\ ${ }^{2}$ Environmental Research Division, National Fisheries Research and Development Institute, 216 Gijanghaean-ro, Gijang-eup, \\ Busan Metropolitan City 46083, Republic of Korea \\ ${ }^{3}$ Marine Environmental Research Center, Korea Institute of Ocean Science \& Technology, 385 Haeyang-ro, Yengdo-gu, \\ Busan Metropolitan City 49111, Republic of Korea
}

\begin{abstract}
We investigated the effects of Manila clam aquaculture on the rates and pathways of anaerobic organic carbon (OC) oxidation in highly bioturbated (HB) and poorly bioturbated (PB) sediment in Keunso Bay, Yellow Sea. Due to the labile organic matter supply via sediment reworking by Manila clams, the anaerobic OC oxidation rate in HB sediment $\left(38.8 \mathrm{mmol} \mathrm{m}^{-2} \mathrm{~d}^{-1}\right)$ was $\sim 1.5$ times higher than that in PB sediment $\left(26.8 \mathrm{mmol} \mathrm{m}^{-2} \mathrm{~d}^{-1}\right)$. Microbial Fe(III) reduction (FeR) dominated OC oxidation pathways in HB sediment, comprising 55 to $76 \%$ of anaerobic OC oxidation, whereas sulfate reduction (SR) was the dominant oxidation pathway in PB sediment, accounting for up to $92 \%$ of anaerobic OC oxidation. Despite higher anaerobic respiration rates at the $\mathrm{HB}$ site, concentrations of $\mathrm{NH}_{4}{ }^{+}, \mathrm{PO}_{4}{ }^{3-}$, oxalate-extractable iron (Fe(II) $($ oxal) $)$, and total reduced inorganic sulfur were 2 to 3 times lower in HB than in PB sediment. Conversely, the concentration of reactive $\mathrm{Fe}(\mathrm{III})_{\text {(oxal) }}$ at the $\mathrm{HB}$ site $\left(2243 \mathrm{mmol} \mathrm{m}^{-2}\right)$ exceeded that at the PB site $(1127 \mathrm{mmol}$ $\mathrm{m}^{-2}$ ) by a factor of 2 . These results indicate that bioturbation by Manila clams enhances the re-oxidation processes of reduced metabolites in the sediment, thereby prohibiting SR and promoting FeR. Overall, the results suggest that aquaculture activities of Manila clams shift the dominant OC oxidation pathways in sediment from SR to FeR, which generates relatively oxidized and less sulfidic environments.
\end{abstract}

KEY WORDS: Aquaculture - Manila clam • Bioturbation - Organic carbon oxidation · Sulfate reduction · Iron reduction

\section{INTRODUCTION}

Aquaculture has expanded rapidly over the last 20 yr due to progressively impoverished natural fish stocks and increased human demand for seafood (Klinger \& Naylor 2012, FAO 2018, Ahmed \& Thompson 2019). The contribution of aquaculture to global fish production has increased steadily, from $20.9 \%$ in 1995 to $46.8 \%$ in 2016 (FAO 2018). Shellfish farming represents a major aquaculture activity, accounting

${ }^{*}$ Corresponding author: hyunjh@hanyang.ac.kr for $21.4 \%$ of total production, with an annual yield in 2016 of 17.1 million t (FAO 2018). Manila clam Ruditapes philippinarum aquaculture increased from 2.6 million $\mathrm{t}$ in 2005 to 4.2 million $\mathrm{t}$ in 2016 and is ranked third in global shellfish production (FAO 2018).

A major environmental concern associated with intensive aquaculture activities is the accumulation of organic matter in sediments (Holmer \& Kristensen 1992, 1994, Holmer et al. 2005, Hyun et al. 2013, Choi et al. 2018). In contrast to finfish farming, where sed-

(C) The authors 2020. Open Access under Creative Commons by Attribution Licence. Use, distribution and reproduction are unrestricted. Authors and original publication must be credited. 
iment receives organic-rich uneaten fish food and fecal materials, shellfish aquaculture is considered less environmentally stressful, as filter-feeding shellfish do not require additional food (Nedwell 2004, Dumbauld et al. 2009). Nevertheless, bivalves eject suspended organic matter trapped from the water column during filter feeding either as pseudo-feces or fecal pellets (Zhou et al. 2006, Zhang et al. 2013, Galimany et al. 2017). Ejected organic matter is larger and more prone to deposition on the sediment, since pseudo-feces and fecal pellets are excreted as mucus-bound aggregates (Giles \& Pilditch 2004). Unlike oysters and mussels, which are generally cultivated in boxes or attached to longlines in the water column (Christensen et al. 2003, Carlsson et al. 2012, Hyun et al. 2013), Manila clams are farmed directly in intertidal sediment after dispersion (Bendell et al. 2010, Lavoie et al. 2016). Accumulation of organic matter and intense sediment reworking (i.e. physical mixing) can have a substantial influence on sediment biogeochemistry (Welsh 2003, McKindsey et al. 2011, Kristensen et al. 2012, Wendelboe et al. 2013, Koo \& Seo 2017, Powilleit \& Forster 2018).

In organic-rich coastal sediments, oxygen is depleted within a few millimeters below the surface (Rasmussen \& Jørgensen 1992, Cai \& Sayles 1996). Thus, most organic carbon (OC) oxidation is performed by a variety of anaerobic microorganisms utilizing different electron acceptors, such as nitrate, manganese oxides, iron oxides, and sulfate (Canfield et al. 2005, Jørgensen 2006). Previous studies have suggested that OC oxidation in coastal sediment is dominated by sulfate reduction (SR) because of the high sulfate concentration in seawater (Howarth 1993, Alongi 1998). However, recent evidence suggests that microbial Fe (III) reduction (FeR) may be comparable to or higher than SR in Fe(III)-rich environments, especially in highly bioturbated sediment (Kostka et al. 2002a, Hyun et al. 2007, 2009, Kristensen 2008, Kristensen et al. 2011, van de Velde \& Meysman 2016). The construction of burrows and subsequent ventilation introduce oxygen from the overlying water during submersion or directly from the air during exposed periods, which stimulates $\mathrm{OC}$ oxidation coupled with both aerobic (i.e. $\mathrm{O}_{2}$ reduction) and suboxic (i.e. FeR) processes (Kostka et al. 2002a,b, Gribsholt et al. 2003, Hyun et al. 2007, 2009).

Most previous studies on the significance of FeR in OC oxidation associated with macrofauna activities in coastal sediment have focused on the burrows constructed in natural sediment by polychaetes (Nereis diversicolor, Arenicola marina, and Marenzelleria viridis) (Kristensen 2000, 2001, Quintana et al. 2013), clams (Mya arenaria and Mytilus galloprovincialis) (Hansen et al. 1996, Nizzoli et al. 2006b), and crabs (Uca pugnax and Cleistostoma dilatatums) (Kostka et al. 2002a,b, Gribsholt et al. 2003, Nielsen et al. 2003, Ferreira et al. 2007, Hyun et al. 2007). However, despite the extent of Manila clam aquaculture, little is known about its influence on sediment biogeochemistry. In this paper, we investigate the biogeochemical impact of burrows created by Manila clam aquaculture on (1) the distribution of chemical constituents in pore water and sediment and (2) the rates and partitioning of OC oxidation by SR and FeR, the 2 most dominant anaerobic OC oxidation pathways in intertidal sediment.

\section{MATERIALS AND METHODS}

\subsection{Study area and sampling}

The west coast of the Korean Peninsula, i.e. the eastern part of the Yellow Sea, is characterized by extensive intertidal wetlands, with an area of approximately $1800 \mathrm{~km}^{2}$, covering $75 \%$ of the total coastal wetlands in South Korea (approximately $2400 \mathrm{~km}^{2}$ ) (Koh \& de Jonge 2014). Commercial production of Manila clams in this area accounts for $70 \%$ of the total production in Korea (Choi et al. 2016). This study was carried out on the intertidal flat in Keunso Bay near the Taean Peninsula (Fig. 1). Keunso Bay covers $87 \mathrm{~km}^{2}$ without influx of rivers or fresh water and has a semi-diurnal macrotidal regime with an average tidal amplitude of approximately $6 \mathrm{~m}$ (Eom et al. 2012, www.khoa.go.kr/eng). The tidal range results in a low hydraulic turnover time (1.32 tidal cycles), indicating that Keunso Bay is a well-flushed environment (Choi et al. 2011). Approximately $70 \%$ of the bay is exposed to air at low tide, and water depth is 2 to $4 \mathrm{~m}$ during high tide (Eom et al. 2012).

Seed clams $(\sim 1.0 \mathrm{~cm}$ in shell length) are spread on the sediment by farmers and harvested when they exceed $3.5 \mathrm{~cm}$ in size (Lim 2016). Manila clams usually inhabit a depth of 3 to $6 \mathrm{~cm}$ in sandy silt sediment with clay content $<10 \%$ (Cho et al. 2001, Nam et al. 2018). They create I-shaped burrows using their foot and have a basket-like filter inside the body cavity that opens to the outside through 2 siphons. Water enters through the inhalant siphon and exits through the exhalant siphon after passage through the filter where particles are retained. Weight-specific filtra- 

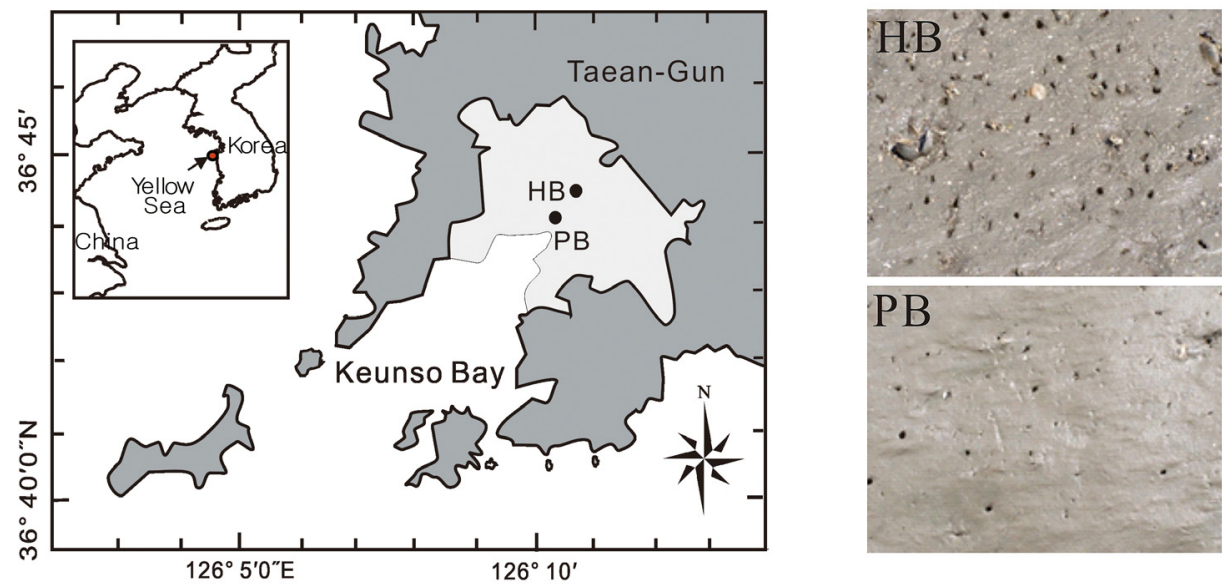

Fig. 1. Study sites of Manila clam aquaculture in the intertidal sediment of Keunso Bay. Light grey: intertidal flats exposed during low tide. Photos: small holes in sediment highly bioturbated (HB) or poorly bioturbated (PB) by Manila clams

tion, or ventilation, of Manila clams ranges from 1.2 to $6.0 \mathrm{l} \mathrm{g}^{-1} \mathrm{~h}^{-1}$ (Nizzoli et al. 2006a), which is lower than rates reported for oysters $\left(8.8 \mathrm{l} \mathrm{g}^{-1} \mathrm{~h}^{-1}\right.$, Riisgård 1988) and mussels (3.5-8.0 $\mathrm{l} \mathrm{g}^{-1} \mathrm{~h}^{-1}$, Riisgård et al. 2013). During filtration, re-oxidation occurs by oxygen diffusion through the siphon wall or passive advection of water coupled with the siphon reaction (Hansen et al. 1996). Feces and pseudo-feces are ejected through an atrial siphon after digestion, providing labile organic matter to microorganisms in the sediment.

Manila clams cultivated at the study sites show highest growth (e.g. filtration and ingestion rates) at temperatures of 15 to $20^{\circ} \mathrm{C}$ in spring (Han et al. 2008). Growth decreases rapidly at temperatures above $25^{\circ} \mathrm{C}$ in summer (Laing et al. 1987), whereas mass mortality occurs during winter because of low temperatures (Kim et al. 2017). To optimize the effects of reworking and ventilation by Manila clams on the rates and pathways of anaerobic OC oxidation, we conducted experiments at a temperature of $18^{\circ} \mathrm{C}$ in the spring of 2008. Sediment samples were collected in 2 contrasting habitats at the same tidal elevation, one in a highly bioturbated (HB) site in the center of the farm and the other in poorly bioturbated (PB) sediment at the edge of the farm (Fig. 1). Average burrow density was estimated by counting burrow openings within 1 quadrat $(25 \times 25 \mathrm{~cm})$ that was cast randomly onto the sediment more than 10 times.

\subsection{Sediment handling}

Triplicate sediment cores were collected using polycarbonate tubes $(10 \mathrm{~cm}$ i.d.) to analyze for pore water solutes and solid phase Fe. The cores were transferred to an $\mathrm{N}_{2}$-filled glove bag, and subsamples were collected from depths of $0-1,1-2,2-3,3-4$, $4-5,5-6,6-8$, and $8-10 \mathrm{~cm}$ and transferred into polypropylene centrifuge tubes. The tubes were tightly capped and centrifuged for $10 \mathrm{~min}$ at 3500 $\mathrm{rpm}$. After reintroduction to the $\mathrm{N}_{2}$-filled glove bag, pore water was sampled and filtered through $0.2 \mu \mathrm{m}$ cellulose acetate syringe filters (Advantec). To determine inorganic nutrient concentrations $\left(\mathrm{NH}_{4}{ }^{+}, \mathrm{NO}_{\mathrm{x}}\right.$ and $\left.\mathrm{PO}_{4}{ }^{3-}\right), 2 \mathrm{ml}$ aliquots of pore water were fixed with $18 \mu$ of saturated $\mathrm{HgCl}_{2}$ and then frozen $\left(-20^{\circ} \mathrm{C}\right)$ until analysis. $\mathrm{Fe}^{2+}$ in pore water was acidified with $12 \mathrm{~N} \mathrm{HCl}$ and stored at $4^{\circ} \mathrm{C}$. After collection of pore water, the remaining sediment was frozen at $-20^{\circ} \mathrm{C}$ for later analysis of oxalate-extractable $\mathrm{Fe}(\mathrm{II})_{\text {(oxal) }}$. Duplicate sediment cores were collected for chl $a$, organic carbon, and nitrogen analyses. The sediment was sectioned as above, loaded into polypropylene conical tubes, and frozen until further laboratory processing.

\subsection{Geochemical analysis}

Sediment temperature was measured using a digital thermometer (Cole-Parmer). Total organic carbon (TOC) and total nitrogen (TN) content was analyzed using a CHN analyzer (EA 1110, CE Instruments) after removal of $\mathrm{CaCO}_{3}$ with $\mathrm{HCl}(10 \%)$. Chl a concentration in the surface sediment $(0-2 \mathrm{~cm})$ was determined using spectrophotometry according to Parsons et al. (1984). The concentration of $\mathrm{NH}_{4}{ }^{+}$in the pore water was measured by flow injection analysis with conductivity detection (detection limit $=5 \mu \mathrm{M}$, 
$\mathrm{SD}=2 \%$, Hall \& Aller 1992). Concentrations of $\mathrm{NO}_{\mathrm{x}}$ and $\mathrm{PO}_{4}{ }^{3-}$ in pore water were measured using an autoanalyzer (detection limit: $0.02 \mu \mathrm{M}, \mathrm{SD}=2 \%$ for $\mathrm{NO}_{\mathrm{x} i} 0.006 \mu \mathrm{M}, \mathrm{SD}=2 \%$ for $\mathrm{PO}_{4}{ }^{3-} ;$ Proxima, Alliance). Dissolved $\mathrm{Fe}^{2+}$ in pore water fixed with $12 \mathrm{~N} \mathrm{HCl}$ was determined by a colorimetric method using ferrozine (detection limit $=1 \mu \mathrm{M}, \mathrm{SD}=2 \%$, Stookey 1970).

Wet chemical extraction was used to determine poorly crystallized iron minerals. The sediment was well mixed and subsampled (ca. $0.4 \mathrm{~g}$ ) before extracting total $\mathrm{Fe}$ and $\mathrm{Fe}(\mathrm{II})$ in an anoxic chamber (vinyl anaerobic chamber, Coy Laboratory Products). Fe(II) was extracted in anoxic oxalate solution prepared by purging $\mathrm{N}_{2}$ gas to prevent oxidation during $\mathrm{Fe}(\mathrm{II})$ extraction (Phillips \& Lovley 1987). Total oxalateextractable $\mathrm{Fe}_{(\text {oxal) }}$ was extracted from air-dried sediment in a $0.2 \mathrm{M}$ oxic oxalate reagent $(\mathrm{pH} 3)$ for more than $4 \mathrm{~h}$ (Thamdrup \& Canfield 1996). Total $\mathrm{Fe}_{\text {(oxal) }}$ and $\mathrm{Fe}(\mathrm{II})_{\text {(oxal) }}$ were determined with ferrozine as described above. Oxalate-extractable solid Fe(III) (oxal) was defined as the difference between total $\mathrm{Fe}_{\text {(oxal) }}$ and Fe(II) (oxal). Total reduced inorganic sulfur (TRIS), including acid-volatile sulfide (AVS $=\mathrm{FeS}+\mathrm{H}_{2} \mathrm{~S}$ ) and chromium-reducible sulfur $\left(\mathrm{CRS}=\mathrm{S}^{0}+\mathrm{FeS}_{2}\right)$, was determined with the methylene blue method (detection limit: $3 \mu \mathrm{M}, \mathrm{SD}=1 \%$, Cline 1969) after singlestep distillation of approximately $1 \mathrm{~g}$ of sediment with cold $12 \mathrm{~N} \mathrm{HCl}$ in boiling $0.5 \mathrm{M} \mathrm{Cr}^{2+}$ solution (Fossing \& Jørgensen 1989).

\subsection{Metabolic rate measurements}

To determine the biogeochemical effect of Manila clams at depths of $3-6 \mathrm{~cm}$, sediment cores down to $10 \mathrm{~cm}$ were collected using acrylic tubes $(10 \mathrm{~cm}$ i.d.). The sediment was cut into depth intervals of $0-2,2-4,4-6$, and $6-10 \mathrm{~cm}$ in $\mathrm{N}_{2}$-filled glove bags. Sediment from parallel sections was pooled, mixed, and loaded into gas-tight plastic bags (Hansen et al. 2000). The bags were sealed without head space and incubated in the dark at in situ temperatures in larger anaerobic bags to ensure anoxic conditions. Subsamples were collected at Days $0,1,2,3$, and 5 to measure the accumulation of dissolved inorganic carbon (DIC) in the pore water. Two $50 \mathrm{ml}$ centrifuge tubes were filled completely with sediment from each bag in $\mathrm{N}_{2}$-filled glove bags, and pore water was extracted by centrifugation. For DIC analysis, $2.0 \mathrm{ml}$ aliquots were transferred into glass vials without a gas space, fixed with $18 \mu \mathrm{l}$ of saturated $\mathrm{HgCl}_{2}$, and stored at $4^{\circ} \mathrm{C}$ for analysis within
2 wk. Total DIC was measured by flow injection analysis with conductivity detection (Hall \& Aller 1992). Total anaerobic OC mineralization rates were determined by linear regression of the accumulation of total DIC with time during anoxic bag incubations (Fig. A1 in the Appendix).

After pore water retrieval from the centrifuge tubes, sediment was homogenized in an $\mathrm{N}_{2}$ atmosphere, and $\mathrm{Fe}(\mathrm{II})_{\text {(oxal) }}$ was extracted in oxalate as described in Section 2.3. FeR was determined by linear regression of the solid-phase $\mathrm{Fe}(\mathrm{II})_{\text {(oxal) }}$ concentration with time during anoxic bag incubations (Kostka et al. 2002a, Fig. A1). Dissimilatory microbial FeR rates were calculated by subtracting abiotic FeR coupled with oxidation of sulfide produced by SR as described in Eq. (1) (Gribsholt et al. 2003):

$$
\text { Dissimilatory FeR }=\text { total FeR }- \text { abiotic FeR }
$$

Abiotic FeR was calculated from FeR coupled with oxidation of $\mathrm{H}_{2} \mathrm{~S}$ produced by $\mathrm{SR}$ using a stoichiometry of 2Fe:3S (Pyzik \& Sommer 1981, Melton et al. 2014). Finally, to elucidate the contribution of FeR in anaerobic OC oxidation, a 4:1 stoichiometry of FeR coupled with OC oxidation was used (Canfield et al. 1993).

SR was determined in triplicate on intact cores ( $3 \mathrm{~cm}$ i.d., $35 \mathrm{~cm}$ long) by the radiotracer method of Jørgensen (1978). Carrier-free ${ }^{35} \mathrm{SO}_{4}{ }^{2-}(2.5 \mu \mathrm{Ci}$, Institute of Isotopes) was injected into ports at $1 \mathrm{~cm}$ intervals, and cores were incubated for $2 \mathrm{~h}$ at in situ temperature. The sediment was then sliced into sections, fixed in $\mathrm{Zn}$ acetate $(20 \%)$, and frozen at $-20^{\circ} \mathrm{C}$ until distillation in the laboratory. The reduced ${ }^{35} \mathrm{~S}$ was recovered by distillation with cold $12 \mathrm{~N} \mathrm{HCl}$ and a boiling acidic $\mathrm{Cr}^{2+}$ solution (Fossing \& Jørgensen 1989). Radioactivity of the reduced ${ }^{35} \mathrm{~S}$ was quantified using a liquid scintillation counter (Tri-Carb 2910 TR, Perkin Elmer). To estimate OC oxidation by SR, the SR values were converted to carbon oxidation using a stoichiometry of 2C:S (Thamdrup \& Canfield 1996).

\section{RESULTS}

\subsection{Physico-chemical properties of sediment}

Surface sediment (0-2 cm depth) temperature was $18^{\circ} \mathrm{C}$ at both sites (Table 1), and chl a content (which is often used as a proxy for the availability of labile organic matter in surface sediment) was (mean $\pm \mathrm{SD}$ ) 
Table 1. Physico-chemical properties of surface sediment (0-2 cm depth) and burrow density at highly bioturbated (HB) and poorly bioturbated $(\mathrm{PB})$ sites. Data are mean $\pm \mathrm{SE}$. Bold: significant difference between HB and PB sites $(p<0.05)$

\begin{tabular}{|lcc|}
\hline Physico-chemical properties & HB site & PB site \\
\hline Temperature $\left({ }^{\circ} \mathrm{C}\right)$ & 18 & 18 \\
Porosity & $0.59 \pm 0.11$ & $0.50 \pm 0.10$ \\
Density $\left(\mathrm{g} \mathrm{cm}^{-3}\right)$ & $1.61 \pm 0.16$ & $1.71 \pm 0.09$ \\
Water content $(\%)$ & $36.7 \pm 7.3$ & $29.1 \pm 6.0$ \\
Chl a $\left(\mathrm{mg} \mathrm{m}^{-2}\right)$ & $185 \pm 21$ & $173 \pm 62$ \\
Burrow density $\left(\mathrm{no} . \mathrm{m}^{-2}\right)$ & $\mathbf{3 2 6} \pm \mathbf{2 5}$ & $\mathbf{3 7} \pm \mathbf{1 2}$ \\
\hline
\end{tabular}

$185 \pm 21$ and $173 \pm 62 \mathrm{mg} \mathrm{m}^{-2}$ at the HB and PB sites, respectively. The burrow density at the HB site was 9 times higher than that at the PB site ( $t$-tests, $\mathrm{p}<0.05)$. Except for burrow density, the overall physico-chemical properties of surface sediment at the HB and PB sites were not statistically different (IBM SPSS Statistics 20).

\subsection{Pore water and solid-phase constituents}

$\mathrm{NH}_{4}{ }^{+}$concentration increased with depth at both the HB and PB sites (Fig. 2a) and was higher at the PB site (160-351 $\mu \mathrm{M})$ compared with the HB site $(26-248 \mu \mathrm{M})$. Concentrations of $\mathrm{NO}_{\mathrm{x}}$ at the HB site $(4.3-16.5 \mu \mathrm{M})$ were higher than those measured at the $\mathrm{PB}$ site $(1.1-16.8 \mu \mathrm{M}) . \mathrm{NO}_{\mathrm{x}}$ concentration decreased with depth to $4-5 \mathrm{~cm}$ and remained relatively constant deeper down at both sites (Fig. 2b). Concentrations of $\mathrm{PO}_{4}{ }^{3-}$ only increased slightly with depth at the HB site but increased steeply below $4 \mathrm{~cm}$ at the PB site (Fig. 2c). Dissolved $\mathrm{Fe}^{2+}$ concentration at the HB site increased from 1 to $4 \mathrm{~cm}$ depth and thereafter decreased with depth, whereas the concentration at the PB site increased gradually with depth from 0 to $3 \mathrm{~cm}$ and then stabilized (Fig. 2d). Concentrations of $\mathrm{SO}_{4}{ }^{2-}$ ranged from 25.5 to $27.7 \mathrm{mM}$ and from 26.2 to $28.2 \mathrm{mM}$ at the HB and PB sites, respectively (Fig. 2e). Depth-integrated inventories of $\mathrm{NH}_{4}{ }^{+}, \mathrm{PO}_{4}{ }^{3-}$, and $\mathrm{Fe}^{2+}$ at the HB site were 2-, 3-, and 3-fold lower, respectively, than those measured at the PB site $(t$-tests, $\mathrm{p}<0.05)$, whereas concentrations of $\mathrm{NO}_{\mathrm{x}}$ and $\mathrm{SO}_{4}{ }^{2-}$ did not differ between sites (Table 2).
The concentration of TOC at the HB site decreased with depth, from $0.80 \%$ at the surface to $0.64 \%$ at a depth of 1 to $2 \mathrm{~cm}$, and then remained constant to 6-8 $\mathrm{cm}$, whereas that at the PB site decreased gradually from $0.81 \%$ at the surface to $0.39 \%$ at a depth of 6 to $8 \mathrm{~cm}$ (Fig. 3a). The concentration of TN ranged from 0.06 to $0.14 \%$ and from 0.04 to $0.14 \%$ at the HB and PB sites, respectively, and showed a pattern similar to the vertical profile of TOC (Fig. 3b). TOC concentration with sediment depth was higher at the HB site than at the PB site (2-way ANOVA, IBM SPSS Statistics, $p=0.037$ ), and the averaged TOC to a depth of 0 to $10 \mathrm{~cm}$ was higher at the HB site than at the PB site (Table 2). TRIS content was low $(<3 \mu \mathrm{mol}$ $\mathrm{cm}^{-3}$ ) to a depth of 2 to $3 \mathrm{~cm}$ and then increased rapidly with depth at the PB site to $15.6 \mu \mathrm{mol} \mathrm{cm}^{-3}$ at 9 to $10 \mathrm{~cm}$ (Fig. 3c). In contrast, TRIS content at the HB site was uniformly low with depth, showing a slight increase to $7.4 \mu \mathrm{mol} \mathrm{cm}{ }^{-3}$ at $10 \mathrm{~cm}$ (Fig. 3c). At the HB site, $\mathrm{Fe}(\mathrm{III})_{\text {(oxal) }}$ content decreased from $36.9 \mathrm{\mu mol} \mathrm{cm}^{-3}$ near the surface to $14.6 \mu \mathrm{mol} \mathrm{cm}{ }^{-3}$ at a depth of 5 to $6 \mathrm{~cm}$ but decreased steeply from $35.7 \mu \mathrm{mol} \mathrm{cm} \mathrm{cm}^{-3}$ at 0 to $1 \mathrm{~cm}$ to $5.3 \mu \mathrm{mol} \mathrm{cm}{ }^{-3}$ at 5 to $6 \mathrm{~cm}$ at the PB site and then remained relatively constant below this depth at both sites (Fig. 3d). Fe(II) (oxal) content increased from $0.6 \mu \mathrm{mol} \mathrm{cm}{ }^{-3}$ near the surface to $22.4 \mu \mathrm{mol} \mathrm{cm}{ }^{-3}$ at 5-6 $\mathrm{cm}$ depth at the HB site and from $4.7 \mu \mathrm{mol} \mathrm{cm} \mathrm{cm}^{-3}$
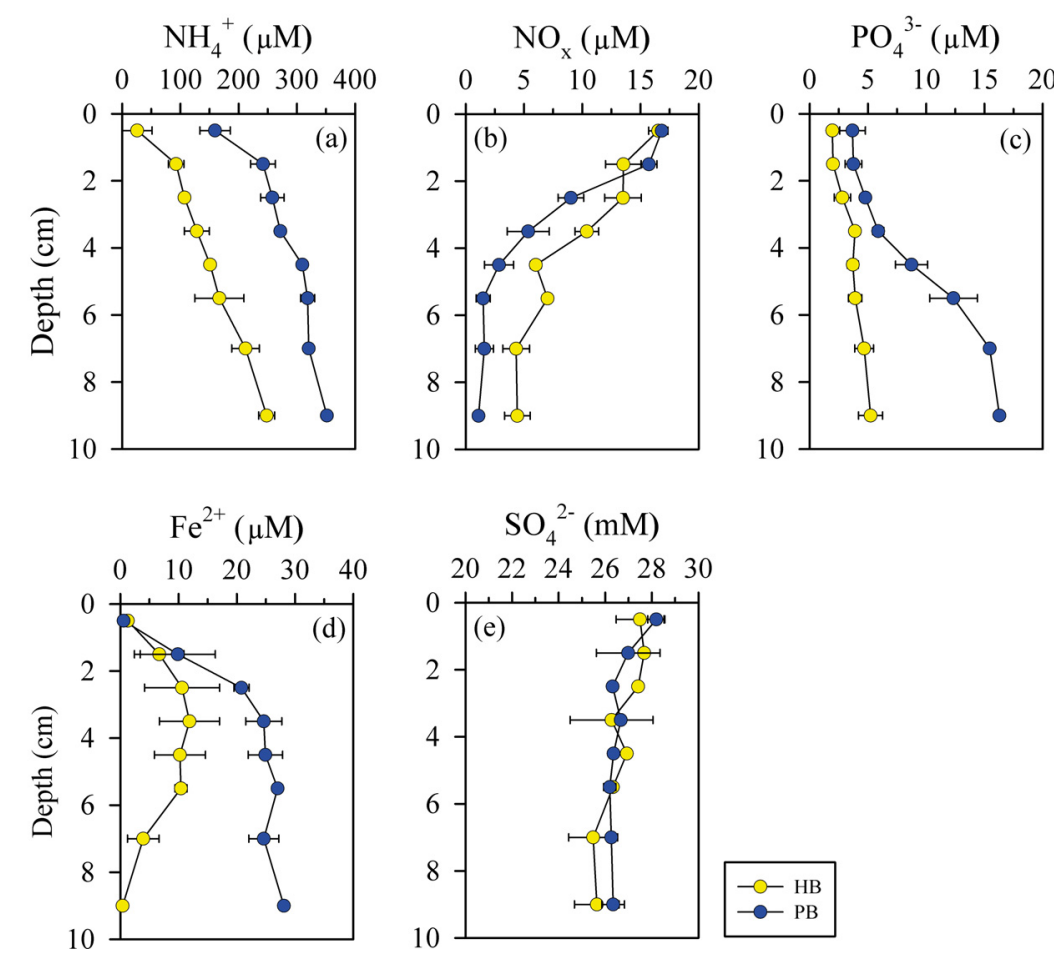

Fig. 2. Vertical profiles of $\mathrm{NH}_{4}{ }^{+}, \mathrm{NO}_{\mathrm{x}}, \mathrm{PO}_{4}{ }^{3-}, \mathrm{Fe}^{2+}$, and $\mathrm{SO}_{4}{ }^{2-}$ in pore water. Horizontal bars indicate SE. HB: highly bioturbated; PB: poorly bioturbated 
Table 2. Depth-integrated $(0-10 \mathrm{~cm})$ concentrations of pore water and solid phase constituents (mean \pm SD) of the duplicate or triplicate samples. Bold: significant difference between highly bioturbated (HB) and poorly bioturbated (PB) sites (p < 0.05). TOC: total organic carbon; TN: total nitrogen; TRIS: total reduced inorganic sulfur

\begin{tabular}{|c|c|c|c|c|c|c|c|c|c|c|}
\hline \multirow[t]{2}{*}{ Site } & & & \multirow{2}{*}{$\begin{array}{l}\text { Pore water } \\
-\left(\mathrm{mmol} \mathrm{m}^{-2}\right) \\
\mathrm{PO}_{4}{ }^{3-}\end{array}$} & & & & Solid phase & \multirow{2}{*}{$\begin{array}{l}\left(\mathrm{mmol} \mathrm{m}{ }^{-2}\right) \\
\mathrm{Fe}(\mathrm{II})_{(\mathrm{oxal})}\end{array}$} & \multirow[b]{2}{*}{$\mathrm{Fe}(\mathrm{III})_{\text {(oxal }}$} \\
\hline & $\mathrm{NH}_{4}{ }^{+}$ & $\mathrm{NO}_{\mathrm{x}}$ & & $\mathrm{Fe}^{2+}$ & $\mathrm{SO}_{4}{ }^{2-}$ & TOC $^{\mathrm{a}}$ & $\mathrm{TN}^{\mathrm{a}}$ & TRIS & & \\
\hline \multirow[t]{2}{*}{ HB } & 7.93 & 0.46 & 0.19 & 0.31 & 1371 & 0.65 & 0.09 & 412 & 1546 & 2243 \\
\hline & \pm 0.40 & \pm 0.01 & \pm 0.01 & \pm 0.14 & \pm 36 & \pm 0.06 & \pm 0.02 & \pm 41 & \pm 56 & \pm 155 \\
\hline \multirow[t]{2}{*}{$\mathrm{PB}$} & 14.17 & 0.29 & 0.49 & 1.04 & 1313 & 0.53 & 0.07 & 946 & 2570 & 1127 \\
\hline & \pm 0.29 & \pm 0.03 & \pm 0.01 & \pm 0.03 & \pm 17 & \pm 0.03 & \pm 0.01 & \pm 39 & \pm 104 & \pm 107 \\
\hline
\end{tabular}

near the surface to $31.7 \mu \mathrm{mol} \mathrm{cm}^{-3}$ at $5-6 \mathrm{~cm}$ depth at the $\mathrm{PB}$ site, mirroring the decrease in Fe(III) (oxal) $_{\text {(oxal) }}$ (Fig. 3d,e). Fe(III) $)_{\text {(oxal) }}$ comprised $>80 \%$ of total Fe (oxal) (i.e. $\mathrm{Fe}(\mathrm{II})+\mathrm{Fe}(\mathrm{III}))$ at $0-4$ and $0-2 \mathrm{~cm}$ depth at the $\mathrm{HB}$ and $\mathrm{PB}$ sites, respectively (Fig. 3d,e). The $\mathrm{Fe}(\mathrm{III})_{\text {(oxal) }}$ fraction of total $\mathrm{Fe}_{\text {(oxal) }}$ decreased to $<20 \%$ below $4 \mathrm{~cm}$ at the $\mathrm{PB}$ site, whereas it remained $>40 \%$ in the upper 6 to $8 \mathrm{~cm}$ of sediment at the HB site (Fig. 3d,e). The solid-phase Fe(III) (oxal) $_{\text {content was }}$ higher at the $\mathrm{HB}$ site than at the $\mathrm{PB}$ site (2-way ANOVA, $p=0.020$ ), whereas solid-phase Fe(II) (oxal) and TRIS contents were higher at the PB site than at the HB site (2-way ANOVA, p $=0.033$ and $\mathrm{p}<$ 0.001 , respectively).

\subsection{Rates of SR and FeR}

SR at the HB site was generally low $(<100 \mathrm{nmol}$ $\mathrm{cm}^{-3} \mathrm{~d}^{-1}$ ) through the entire sediment depth, with the highest rate measured at 1 to $2 \mathrm{~cm}$ (Fig. $4 \mathrm{a}$ ). In contrast, SR at the PB site increased from $36.4 \mathrm{nmol} \mathrm{cm}^{-3}$ $\mathrm{d}^{-1}$ near the surface layer $(0-1 \mathrm{~cm})$ to $262.6 \mathrm{nmol} \mathrm{cm}^{-3}$ $\mathrm{d}^{-1}$ at $1-2 \mathrm{~cm}$ depth and then decreased to $33.6 \mathrm{nmol}$ $\mathrm{cm}^{-3} \mathrm{~d}^{-1}$ at 9-10 $\mathrm{cm}$ depth (Fig. 4d). SR was higher at the $\mathrm{PB}$ site than at the $\mathrm{HB}$ site with sediment depth (2-way ANOVA, $\mathrm{p}=0.002)$, and depth-integrated $(0-10 \mathrm{~cm})$ SR was approximately 1.4 times higher at the PB site than at the HB site (Table 3).

FeR at the HB site was highest in the 0-2 $\mathrm{cm}$ interval $\left(2172 \mathrm{nmol} \mathrm{cm}^{-3} \mathrm{~d}^{-1}\right)$ and then decreased consistently with depth to

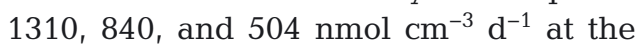
2-4, 4-6, and 6-10 cm intervals, respectively (Fig. 4b). FeR at the PB site was 2433 and $648 \mathrm{nmol} \mathrm{cm}^{-3} \mathrm{~d}^{-1}$ at the $0-2$ and 2-4 cm depth intervals, respectively, and then decreased to $0-168 \mathrm{nmol} \mathrm{cm}^{-3} \mathrm{~d}^{-1}$ at the 4-10 cm interval (Fig. 4e). Depthintegrated $(0-10 \mathrm{~cm}) \mathrm{FeR}$ at the HB site was 1.8 times higher than at the PB site ( $t$-tests, $\mathrm{p}<0.05$, Table 3$)$.

\subsection{Total anaerobic $\mathrm{OC}$ oxidation rate}

Anaerobic respiration at the $\mathrm{HB}$ site decreased gradually from 704 to $215 \mathrm{nmol}$ $\mathrm{C} \mathrm{cm}^{-3} \mathrm{~d}^{-1}$ with depth, whereas it rapidly decreased with depth from 666 to $82 \mathrm{nmol}$
Fig. 3. Vertical profiles of total organic carbon (TOC), total nitrogen (TN), total reduced inorganic sulfur (TRIS), solid-phase Fe(II), and Fe(III) in the sediment. Horizontal bars indicate SE. HB: highly bioturbated; PB: poorly bioturbated 
Sulfate reduction rate (nmol S cm ${ }^{-3} \mathrm{~d}^{-1}$ )
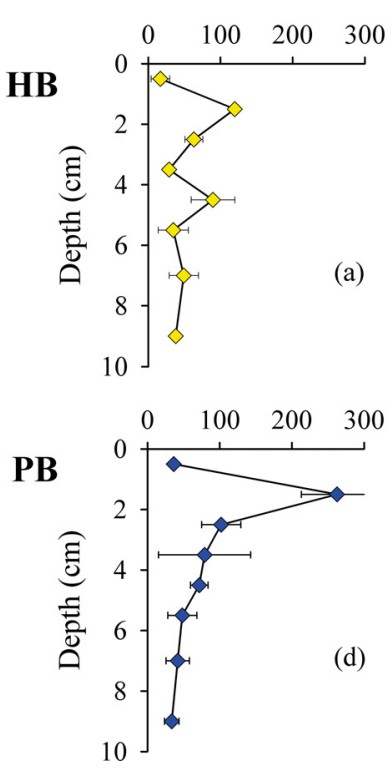

Fe reduction rate (nmol Fe $\mathrm{cm}^{-3} \mathrm{~d}^{-1}$ )
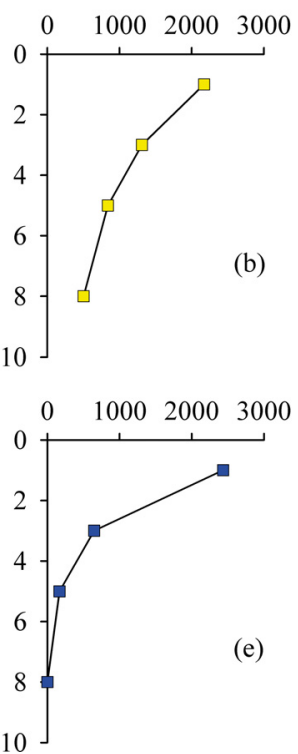

C oxidation rate (nmol C $\mathrm{cm}^{-3} \mathrm{~d}^{-1}$ )
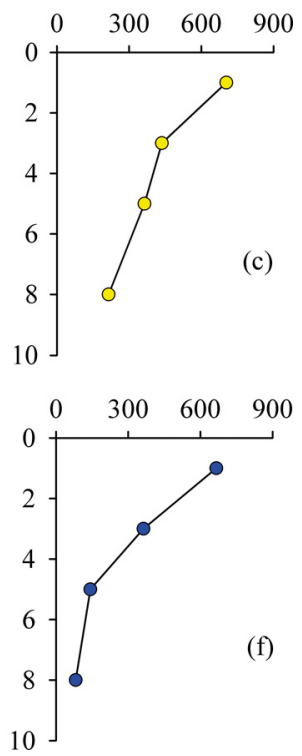

Fig. 4. Sulfate reduction from whole-core analyses, Fe reduction, and anaerobic carbon oxidation (dissolved inorganic carbon production rates) measured using anoxic bag incubation. Horizontal bars indicate SE. HB: highly bioturbated; PB: poorly bioturbated $\mathrm{cm}^{-3} \mathrm{~d}^{-1}$ at the PB site (Fig. 4c,f). Depthintegrated $(0-10 \mathrm{~cm})$ anaerobic OC respiration rate at the $\mathrm{HB}$ site was significantly higher than at the PB site $(t$-tests, $\mathrm{p}<0.05$, Table 3).

\section{DISCUSSION}

\subsection{Impacts of Manila clams on sediment geochemistry and OC oxidation}

One of the distinguishing observations of this study was that anaerobic OC oxidation at the $\mathrm{HB}$ site exceeded that at the PB site to a depth of $10 \mathrm{~cm}$ (Fig. 4, Table 3). Anaerobic OC oxidation at both the $\mathrm{HB}$ and $\mathrm{PB}$ sites represented maximum values in surface sediment (0-2 cm); however, it decreased rapidly with depth at the PB site due to the lack of OC supply into the sediment. Suspension-feeding bivalves filter a large volume of suspended particles from the water

Table 3. Partitioning of sulfate and Fe(III) reduction in anaerobic organic carbon (OC) oxidation $\left(\mathrm{mmol} \mathrm{m}^{-2} \mathrm{~d}^{-1}\right)$. HB: highly bioturbated; PB: poorly bioturbated; nd: not detected

\begin{tabular}{|c|c|c|c|c|c|c|c|c|}
\hline Site & Depth & Anaerobic OC & Sulfate & Total Fe(III) & - Fe(III) rec & tion by ${ }^{\mathrm{a}, \mathrm{b}}-$ & - OC oxida & tion by ${ }^{\mathrm{a}, \mathrm{c}}$ \\
\hline & $(\mathrm{cm})$ & oxidation & reduction & reduction & $\begin{array}{l}\text { Sulfide } \\
\text { oxidation }\end{array}$ & $\begin{array}{c}\mathrm{Fe}(\mathrm{III}) \\
\text { reducer }\end{array}$ & $\begin{array}{l}\text { Microbial sulfate } \\
\text { reduction }\end{array}$ & $\begin{array}{l}\text { Microbial Fe(III) } \\
\text { reduction }\end{array}$ \\
\hline $\mathrm{HB}$ & $0-2$ & 14.1 & 1.4 & 43.4 & $0.93(2.1 \%)$ & $42.51(97.9 \%)$ & $2.8(19.9 \%)$ & $10.63(75.5 \%)$ \\
\hline & $2-4$ & 8.8 & 0.9 & 26.2 & $0.60(2.3 \%)$ & $25.61(97.7 \%)$ & $1.8(20.5 \%)$ & $6.4(72.8 \%)$ \\
\hline & $4-6$ & 7.3 & 1.2 & 16.8 & $0.83(4.9 \%)$ & $15.97(95.1 \%)$ & $2.5(34.1 \%)$ & $4.0(54.9 \%)$ \\
\hline & $6-10$ & 8.6 & 1.7 & 20.2 & $1.16(3.3 \%)$ & $19.00(96.7 \%)$ & $3.5(40.4 \%)$ & $4.8(55.2 \%)$ \\
\hline Sur & $\mathrm{m}(0-10)$ & 38.8 & 5.3 & 103.3 & $3.57(3.5 \%)$ & $99.63(96.5 \%)$ & $10.6(29.1 \%)$ & $25.8(70.8 \%)$ \\
\hline PB & $0-2$ & 13.3 & 1.2 & 48.7 & $0.83(1.7 \%)$ & $47.85(98.3 \%)$ & $2.4(18.6 \%)$ & $12.0(89.7 \%)$ \\
\hline & $2-4$ & 7.3 & 1.8 & 13.0 & $1.21(9.3 \%)$ & $11.75(90.7 \%)$ & $3.6(49.8 \%)$ & $2.9(40.4 \%)$ \\
\hline & $4-6$ & 2.9 & 1.0 & 3.4 & $0.67(19.6 \%)$ & $2.73(80.4 \%)$ & $2.0(69.0 \%)$ & $0.7(23.6 \%)$ \\
\hline & $6-10$ & 3.3 & 1.5 & 0.0 & nd & nd & $3.0(91.8 \%)$ & nd \\
\hline Sur & $\mathrm{m}(0-10)$ & 26.8 & 7.4 & 56.2 & $2.78(4.3 \%)$ & $62.22(95.7 \%)$ & $11.0(41.1 \%)$ & $15.6(58.3 \%)$ \\
\hline
\end{tabular}

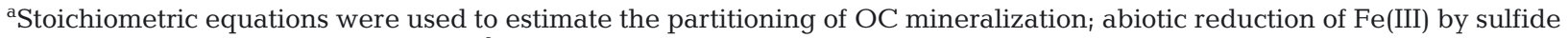
oxidation: $3 \mathrm{H}_{2} \mathrm{~S}+2 \mathrm{FeOOH}=2 \mathrm{FeS}+\mathrm{S}^{0}+4 \mathrm{H}_{2} \mathrm{O}$; microbial Fe(III) reduction = total Fe(III) reduction - abiotic Fe(III) reduction; OC oxidation by sulfate reduction: $\mathrm{SO}_{4}{ }^{2-}+\mathrm{CH}_{3} \mathrm{COO}^{-}+2 \mathrm{H}^{+}=2 \mathrm{CO}_{2}+2 \mathrm{H}_{2} \mathrm{O}+\mathrm{HS}^{-}$; OC mineralization by microbial Fe(III) reduction: $4 \mathrm{FeOOH}+\mathrm{CH}_{3} \mathrm{COO}^{-}+8 \mathrm{H}^{+}=\mathrm{CO}_{2}+7 \mathrm{H}_{2} \mathrm{O}+4 \mathrm{Fe}^{2+}$

${ }^{\mathrm{b}}$ Relative contribution (\%) of abiotic and microbial Fe(III) reduction in total Fe(III) reduction

${ }^{\mathrm{c}}$ Relative contribution (\%) of sulfate reduction and Fe(III) reduction to total anaerobic OC respiration 
column and eject uningested pseudo-feces and unassimilated feces into the sediment. Those feces are reactive and have low $\mathrm{C}: \mathrm{N}$ molar ratios and are therefore suitable for stimulating benthic metabolism (Nedwell 2004, Varela et al. 2004). The difference in anaerobic OC oxidation rate between $\mathrm{HB}$ and $\mathrm{PB}$ sites was most distinct below $4 \mathrm{~cm}$ depth (Table 3). Studies on excavation and feeding behaviors of fiddler crabs have reported that bioturbation greatly modifies the distribution of organic matter (Botto \& Iribarne 2000, Kristensen \& Alongi 2006, Natálio et al. 2017), thereby stimulating benthic microbial remineralization in subsurface sediment (Kristensen 2000, Lohrer et al. 2005, Martinez-Garcia et al. 2015). In this study, depth distribution of TOC and rates of OC oxidation also showed a high linear correlation $\left(\mathrm{r}^{2}=\right.$ $0.722, \mathrm{p}<0.05)$, which suggests that macrofauna promote vertical transport of organic matter by redistributing particles along their burrows (Aller 1982, Aller \& Aller 1998, Tang \& Kristensen 2007, Bonaglia et al. 2014, Benelli et al. 2017).

Despite higher anaerobic OC oxidation at the $\mathrm{HB}$ site, accumulation of the reduced products of anaerobic metabolic activities (i.e. $\mathrm{NH}_{4}{ }^{+}, \mathrm{PO}_{4}{ }^{3-}$, and $\mathrm{Fe}^{2+}$ ) in the pore water and reduced solid phase iron and

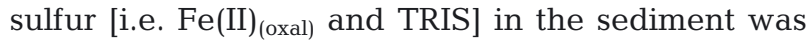
lower at the HB site than at the PB site (Figs. $2 \& 3$, Tables $2 \& 3$ ). In contrast, Fe(III) (oxal) content was higher at the HB site. The results indicate that the reduced inorganic metabolites produced during OC oxidation were either actively re-oxidized or flushed out by bioirrigation because there was no difference in inundation frequency and sediment particle size composition of sediment that could affect the depth profiles of chemical constituents in pore water and the solid phase. The construction of ventilated burrows and irrigation stimulate an exchange of solutes between the sediment and overlying water and drive reduced metabolites out of and oxidized electron acceptors into the sediment (Kristensen \& Kostka 2005, Timmermann et al. 2006, Quintana et al. 2015). Suspension feeders including the Manila clam ventilate large amounts of water to satisfy their demand for food (Kristensen et al. 2012). Furthermore, the biogenic microtopography termed bioroughness (e.g. burrow excavations, feeding traces, and fecal pellets) creates advective pore water flow and forces overlying water into the sediment (Huettel \& Gust 1992). In addition, tidal water intrusion resulting from the large tidal ranges in the study area (average $=6 \mathrm{~m}$, Eom et al. 2012) also affects the inventories of geochemical constituents in the pore water and sediment (Figs. 2 \& 3, Table 2). Consequently, bioturbation by
Manila clams and tidal inundation enhance the exchange of solutes between the pore water and surface water, thereby increasing re-oxidation and transport of reduced metabolites out of the sediment.

\subsection{Partitioning of OC oxidation by $\mathrm{SR}$ and FeR}

Ventilation by macrofauna promotes irrigation and thus re-oxidation of reduced compounds in sediment, which may stimulate degradation of organic matter by suboxic OC oxidation pathways (Aller 1994, Kristensen 2001). In the present study, microbial FeR dominated anaerobic OC oxidation at the HB site, accounting for $70.8 \%$ of the total anaerobic OC oxidation in the $0-10 \mathrm{~cm}$ sediment (Fig. 4, Table 3). FeR accounted for 54.9 to $55.2 \%$ of total anaerobic OC oxidation in the subsurface sediment layers $(4-10 \mathrm{~cm})$ at the HB site, which was still comparable to or higher than the contribution of SR, representing 34.1 to $40.4 \%$ of anaerobic OC oxidation (Fig. 4, Table 3). In contrast, SR was the dominant OC oxidation pathway below $2 \mathrm{~cm}$ of the sediment at the PB site, accounting for 49.8 to $91.8 \%$ of the total anaerobic OC oxidation (Fig. 4, Table 3). Our observations of high FeR under high Fe(III) conditions are similar to results of previous studies reported at highly bioturbated intertidal sediment (Kostka et al. 2002a,b, Gribsholt et al. 2003, Hyun et al. 2007, 2009). Oxygen can penetrate more deeply into highly bioturbated sediment through the burrows, which stimulates reoxidation of Fe(II) to Fe(III) (Kristensen et al. 2012). Consequently, the dominance of FeR in the anoxic part of the sediment at the HB site was induced by the enhanced Fe(III) content, which ultimately suppresses SR (Hines \& Jones 1985, Gribsholt \& Kristensen 2002, Kristensen \& Kostka 2005).

Stocking density is a significant factor for determining production rates in aquaculture (Hengsawat et al. 1997, Jones \& Ruscoe 2000). Lower stocking densities eventually result in less competition and faster growth, but production cost per individual is higher (Rheault \& Rice 1995, Verspecht et al. 2011). In contrast, high stocking densities cause stress from competition for food and space and pathogen infestation, which can lead to mass mortality of aquaculture organisms (Wilber \& Wilber 1991, Dittel et al. 1995, Sheen 2000). Numerous studies have been carried out to determine the optimal stocking density in farm operations to maximize production rates $(\mathrm{Wu}$ et al. 1994, Azim et al. 2001, De Silva 2003, Biswas \& Takii 2017). From a biogeochemical viewpoint, stocking density is also the main factor in controlling the envi- 
ronmental impact of a Manila clam farm. For example, Welsh et al. (2015) reported that the flux of solutes $\left(\mathrm{O}_{2}, \mathrm{~N}_{2}, \mathrm{~N}_{2} \mathrm{O}, \mathrm{NH}_{4}{ }^{+}\right.$, and $\left.\mathrm{NO}_{\mathrm{x}}\right)$, nitrification, and denitrification were significantly correlated with Manila clam density in the Po River Delta, Italy. Extremely high stock density (>1000 ind. $\mathrm{m}^{-2}$ ) was associated with increased anaerobic metabolism, accumulation of reduced compounds, and even chronic hypoxia at a Manila clam farm in the Sacca di Goro Lagoon, Po River Delta (Bartoli et al. 2001, Meliá et al. 2003). In the present study, the dominance of FeR $(>70 \%)$ in OC oxidation together with low TOC content $(<1 \%)$ at the HB site (Tables $2 \& 3$ ) implies that a stock density of approximately 300 ind. $\mathrm{m}^{-2}$ provides environmentally sustainable conditions by lowering overall respiration rates and rapidly replenishing Fe oxides to support FeR, thereby suppressing SR. Because higher accumulation of $\mathrm{OC}$ resulting from extremely high stocking densities would increase $\mathrm{SR}$, studies on the carrying capacity of Manila clam aquaculture that consider multiple environmental and eco-physiological aspects need to be conducted.

\subsection{Dependence of FeR on Fe(III) concentration}

FeR in the sediment is highly dependent on the availability of both reactive $\mathrm{Fe}(\mathrm{III})$ and labile OC (Thamdrup 2000). In organic-rich coastal sediment, re-oxidation of $\mathrm{Fe}(\mathrm{II})$ to $\mathrm{Fe}(\mathrm{III})$ mediated by bioturbation can sustain high rates of microbial FeR (Gribsholt \& Kristensen 2002, Quintana et al. 2015, van de Velde \& Meysman 2016). Indeed, more than $50 \%$ of total anaerobic OC oxidation was processed by FeR at the HB site, where $\mathrm{Fe}(\mathrm{III})_{\text {(oxal) }}$ concentration was

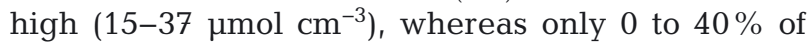
total anaerobic OC oxidation was ascribed to FeR in sediment 2 to $10 \mathrm{~cm}$ deep at the PB site, where less $\mathrm{Fe}(\mathrm{III})_{\text {(oxal) }}\left(2-14 \mu \mathrm{mol} \mathrm{cm}{ }^{-3}\right)$ was available (Table 3). To further verify the dependence of FeR on the availability of Fe(III), we plotted the 2 variables using Eq. (2), which was proposed in a study of coastal sediment (Jensen et al. 2003, Kristensen et al. 2011):

$$
\left.\% \mathrm{FeR}=100\left(1-\mathrm{e}^{-a[\mathrm{Fe}(\mathrm{III})}\right]\right)
$$

where $\% \mathrm{FeR}$ is $\mathrm{OC}$ oxidation through $\mathrm{FeR}$ as a percentage of total anaerobic OC oxidation, $\mathrm{Fe}(\mathrm{III})$ is the concentration of poorly crystalline Fe oxides, and $a$ is the fitting parameter. The contribution of FeR to anaerobic respiration in sediment from Manila clam farms was significantly related to the concentration of reactive Fe(III) (Fig. 4). The relationship shows that more than $70 \%$ of the anaerobic OC oxidation was due to microbial FeR when the concentration of reactive Fe(III) exceeded about $30 \mu \mathrm{mol} \mathrm{cm}^{-3}$ (Fig. 5). The fitting parameter in this study was slightly lower $(a=0.042)$ than that for marine sediment reported from the Danish coastal area $(a=0.056$, Jensen et al. 2003) and mangrove sediment $(a=0.053$, Kristensen et al. 2011) but was higher than that from freshwater sediment $(a=0.029$, Roden \& Wetzel 2002). The variance may result from differences in estimating FeR and extraction methods of Fe(III). Jensen et al. (2003) calculated total anaerobic OC respiration as the sum of OC oxidation by SR and FeR assuming that the 2 pathways constitute most of the anaerobic OC oxidation. The OC oxidation by FeR was then estimated by subtracting the OC oxidation by SR from total anaerobic OC respiration. Considering that SR and FeR are the 2 major OC oxidation pathways (Jensen et al. 2003), the contribution of FeR to anaerobic respiration in this approach can be overestimated because other potentially significant OC oxidation pathways (e.g. denitrification) are neglected. On the other hand, solid phase Fe in mangrove and freshwater sediment is extracted by $\mathrm{HCl}$ according to Lovley \& Phillips (1987) (Roden \& Wetzel 2002, Kristensen et al. 2011). Oxalate and $\mathrm{HCl}$ extraction methods are

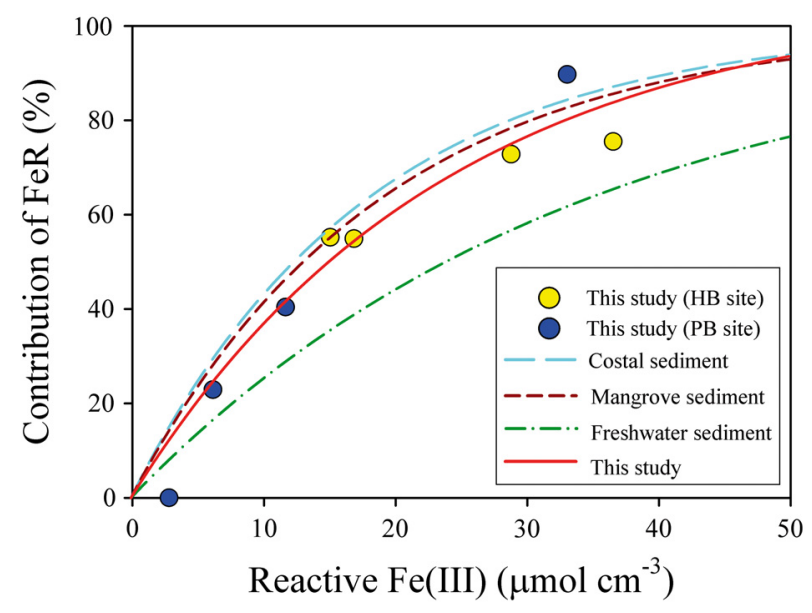

Fig. 5. Relative contribution of Fe(III) reduction (FeR) to anaerobic carbon oxidation as a function of reactive Fe(III) content in sediment. The red line shows the best fit of the data from Manila clam aquaculture sediment using Eq. (2) (Section 4.3) with $a=0.042$. The blue line shows the general relationship of FeR to anaerobic carbon oxidation in coastal sediment using $a=0.056$ as reported by Jensen et al. (2003). The brown line shows the relationship of FeR to anaerobic carbon oxidation in mangrove sediment using $a=0.053$ (Kristensen et al. 2011). The green line represents the relationship of FeR to anaerobic carbon oxidation using $a=0.029$ for freshwater wetlands (Roden \& Wetzel 2002). HB: highly bioturbated; PB: poorly bioturbated 
widely used to determine the poorly crystalline (i.e. reactive) $\mathrm{Fe}$ fraction in sediment (Thamdrup et al. 1994). The major difference between the oxalate and $\mathrm{HCl}$ methods is that $\mathrm{HCl}$ extraction does not capture magnetite, a type of poorly crystalline Fe (Poulton \& Canfield 2005). Although the fitting parameter for $\mathrm{Fe}(\mathrm{III})$ concentration and FeR varies according to method of extraction and calculation of Fe concentration, the tight relationship between $\mathrm{Fe}(\mathrm{III})$ content and contribution of FeR to OC oxidation serves as an extensively adopted proxy to evaluate the significance of FeR and the redox conditions in the sediment of Manila clam aquaculture.

\section{CONCLUSIONS}

A combination of the analysis of sediment constituents as well as rates and partitioning of OC oxidation (i.e. relative significance of $\mathrm{SR}$ and $\mathrm{FeR}$ in anaerobic OC oxidation) was conducted to elucidate the effects of bioturbation by Manila clams on sediment biogeochemistry. Our results revealed that enhanced supply of reactive Fe(III) via increased solute exchange through sediment reworking and irrigation activities by Manila clams ultimately promoted OC oxidation coupled with FeR in the sediment of the aquaculture farms. In contrast to net cage and longline aquaculture, in which SR is the dominant OC oxidation process, Manila clam farms operated with an appropriate stock density in the intertidal sediment have a positive environmental effect in terms of expediting re-oxidation of reduced metabolic compounds, stimulation of FeR, and suppression of SR.

Acknowledgements. This research was supported by the National Institute of Fisheries Science (R2020050) and the Korean Long-term Marine Ecological Research (K-LTMER) program funded by the Korean Ministry of Oceans and Fisheries. Biogeochemical analysis and metabolic rate measurements were supported by the mid-career scientist research program funded by the Korean Ministry of Science and the ICT (No. 2018R1A2B2006340) and partly by a grant from the Korean Institute of Ocean Science and Technology (KIOST, PE99812). We are grateful to the reviewers and editor for their comments that improved the earlier version of this manuscript.

\section{LITERATURE CITED}

Ahmed N, Thompson S (2019) The blue dimensions of aquaculture: a global synthesis. Sci Total Environ 652: 851-861

Aller RC (1982) The effects of macrobenthos on chemical properties of marine sediment and overlying water. In: McCall PL, Tevesz MJS (eds) Animal-sediment relations. Plenum Press, New York, NY, p 53-102
Aller RC (1994) Bioturbation and remineralization of sedimentary organic matter: effects of redox oscillation. Chem Geol 114:331-345

* Aller RC, Aller JY (1998) The effect of biogenic irrigation intensity and solute exchange on diagenetic reaction rates in marine sediments. J Mar Res 56:905-936

Alongi DM (1998) Coastal ecosystem processes. CRC Press, Boca Raton, FL, p 43-92

Azim ME, Wahab MA, van Dam AA, Beveridge MCM, Huisman EA, Verdegem MCJ (2001) Optimization of stocking ratios of two Indian major carps, rohu (Labeo rohita Ham.) and catla (Catla catla Ham.) in a periphyton-based aquaculture system. Aquaculture 203:33-49

Bartoli M, Nizzoli D, Viaroli P, Turolla E, Castaldelli G, Fano $\mathrm{AE}$, Rossi R (2001) Impact of Tapes philippinarum farming on nutrient dynamics and benthic respiration in the Sacca di Goro. Hydrobiologia 455:203-212

* Bendell LI, Duckham C, L'Espérance T, Whiteley JA (2010) Changes in geochemical foreshore attributes as a consequence of intertidal shellfish aquaculture: a case study. Mar Ecol Prog Ser 404:91-108

Benelli S, Batoli M, Racchetti E, Moraes PC, Zilius M, Lubiene I, Fano EA (2017) Rare but large bivalves alter benthic respiration and nutrient recycling in riverine sediments. Aquat Ecol 51:1-16

*Biswas A, Takii K (2017) Optimal stocking density with the provision of self-feeders for striped knifejaw, Oplegnathus fasciatus (Temminck and Schlegel 1844). J World Aquacult Soc 48:488-495

* Bonaglia S, Nascimento FJA, Bartoli M, Klawonn I, Brüchert V (2014) Meiofauna increases bacterial denitrification in marine sediments. Nat Commun 5:5133

Botto F, Iribarne O (2000) Contrasting effects of two burrowing crabs (Chasmagnathus granulate and Uca uruguayensis) on sediment composition and transport in estuarine environments. Estuar Coast Shelf Sci 51:141-151

Cai WJ, Sayles FL (1996) Oxygen penetration depths and fluxes in marine sediments. Mar Chem 52:123-131

* Canfield DE, Thamdrup B, Hansen JW (1993) The anaerobic degradation of organic matter in Danish coastal sediments: iron reduction, manganese reduction, and sulfate reduction. Geochim Cosmochim Acta 57:3867-3883

Canfield DE, Thamdrup B, Kristensen E (2005) Aquatic geomicrobiology, Vol 48. Elsevier, San Diego, CA

Carlsson MS, Engström P, Lindahl O, Ljungqvist L, Petersen JK, Svanberg L, Holmer M (2012) Effects of mussel farms on the benthic nitrogen cycle on the Swedish west coast. Aquacult Environ Interact 2:177-191

Cho TC, Lee SB, Kim SY (2001) Sedimentological and hydromechanical characteristics of bed deposits for the cultivation of Manila clam, Ruditapes philippinarum in Gomso tidal flat. J Korean Fish Soc 34:245-253 (in Korean with English Abstract)

Choi JK, Ruy JH, Woo HJ, Eom J (2011) A study on the flushing characteristic in Geunso Bay using hydro-hypsographic analysis. J Wet Res 13:45-52 (in Korean with English Abstract)

Choi YH, Choi YS, Cho YS, Kim YT, Jeon SR (2016) A study on the habitat suitability considering survival, growth, environment for Ruditapes philippinarum in Geunso Bay (Pado and Beopsan). J Korean Soc Mar Environ Saf 22: 723-730 (in Korean with English Abstract)

Choi A, Cho H, Kim B, Kim HC, Jung RH, Lee WC, Hyun JH (2018) Effects of finfish aquaculture on biogeochemistry and bacterial communities associated with sulfur cycles 
in highly sulfidic sediments. Aquacult Environ Interact 10:413-427

* Christensen PB, Glud RN, Dalsgaard T, Gillespie P (2003) Impacts of long line mussel farming on oxygen and nitrogen dynamics and biological communities of coastal sediments. Aquaculture 218:567-588

Cline JD (1969) Spectrophotometric determinations of hydrogen sulfide in natural waters. Limnol Oceanogr 14:454-458

* De Silva SS (2003) Culture-based fisheries: an underutilized opportunity in aquaculture development. Aquaculture 221:221-243

Dittel AI, Hines AH, Ruiz GM, Run KK (1995) Effects of shallow water refuge on behavior and density-dependent mortality of juvenile blue crabs in Chesapeake Bay. Bull Mar Sci 57:902-916

Dumbauld BR, Ruesink JL, Rumrill SS (2009) The ecological role of bivalve shellfish aquaculture in the estuarine environment: a review with application to oyster and clam culture in West Coast (USA) estuaries. Aquaculture 290:196-223

Eom J, Choi JK, Ryu JH, Woo HJ, Won JS, Jang S (2012) Tidal channel distribution in relation to surface sedimentary facies based on remotely sensed data. Geosci J 16: $127-137$

FAO (Food and Agriculture Organization of the United Nations) (2018) The state of the world fisheries and aquaculture 2018: meeting the sustainable development goals. FAO, Rome

Ferreira TO, Otero XL, Vidal-Torrado P, Macías F (2007) Effects of bioturbation by root and crab activity on iron and sulfur biogeochemistry in mangrove substrate. Geoderma 142:36-46

Fossing H, Jørgensen BB (1989) Measurement of bacterial sulfate reduction in sediments: evaluation of a single-step chromium reduction method. Biogeochemistry 8:205-222

Galimany E, Lunt J, Freeman CJ, Reed S, Segura-García I, Paul VJ (2017) Deeding behavior of eastern oyster Crassostera virginica and hard clams Mercenaria mercenaria in shallow estuaries. Mar Ecol Prog Ser 567:125-137

* Giles H, Pilditch CA (2004) Effects of diet on sinking rates and erosion thresholds of mussel Perna canaliculus biodeposits. Mar Ecol Prog Ser 282:205-219

Gribsholt B, Kristensen E (2002) Effects of bioturbation and plant roots on salt marsh biogeochemistry: a mesocosm study. Mar Ecol Prog Ser 241:71-87

Gribsholt B, Kostka JE, Kristensen E (2003) Impact of fiddler crabs and plant roots on sediment biogeochemistry in a Georgia saltmarsh. Mar Ecol Prog Ser 259:237-251

Hall POJ, Aller RC (1992) Rapid small-volume, flow injection analysis for $\mathrm{CO}_{2}$ and $\mathrm{NH}_{4}{ }^{+}$in marine and freshwaters. Limnol Oceanogr 37:1113-1119

Han KN, Lee SW, Wang SY (2008) The effect of temperature on the energy budget of the Manila clam, Ruditapes philippiarum. Aquacult Int 16:143-152

Hansen K, King GM, Kristensen E (1996) Impact of the softshell clam Mya arenaria on sulfate reduction in an intertidal sediment. Mar Ecol Prog Ser 10:181-194

Hansen JW, Thamdrup B, Jørgensen BB (2000) Anoxic incubation of sediment in gas-tight plastic bags: a method for biogeochemical process studies. Mar Ecol Prog Ser 208: 273-282

Hengsawat K, Ward FJ, Jaruratjamorn P (1997) The effect of stocking density on yield, growth and mortality of African catfish (Clarias gariepinus Burchell 1822) cultured in cages. Aquaculture 152:67-76
Hines M, Jones GE (1985) Microbial biogeochemistry and bioturbation in the sediments of Great Bay, New Hampshire. Estuar Coast Shelf Sci 20:729-742

*Holmer M, Kristensen E (1992) Impact of marine fish cage farming on metabolism and sulfate reduction of underlying sediments. Mar Ecol Prog Ser 80:191-201

Kolmer M, Kristensen E (1994) Organic matter mineralization in an organic-rich sediment: experimental stimulation of sulfate reduction by fish food pellets. FEMS Microbiol Ecol 14:33-44

Holmer M, Wildsh D, Hargrave B (2005) Organic enrichment from marine finfish aquaculture and effects on sediment biogeochemical processes. In: Hargrave BT (ed) Environmental effects of marine finfish aquaculture. Handbook of environmental chemistry, Vol 5M. Springer, Berlin, p 181-206

Howarth RW (1993) Microbial processes in salt-marsh sediments. In: Ford TE (ed) Aquatic microbiology: an ecological approach. Blackwell, Malden, MA, p 239-259

* Huettel M, Gust G (1992) Impact of bioroughness on interfacial solute exchange in permeable sediments. Mar Ecol Prog Ser 89:253-267

* Hyun JH, Smith AC, Kostka JE (2007) Relative contributions of sulfate- and iron(III) reduction to organic matter mineralization and process controls in contrasting habitats of the Georgia saltmarsh. Appl Geochem 22: 2637-2651

*HHyun JH, Mok JS, Cho HY, Kim SH, Lee KS, Kostka JE (2009) Rapid organic matter mineralization coupled to iron cycling in intertidal mud flats of the Han River estuary, Yellow Sea. Biogeochemistry 92:231-245

*Hyun JH, Kim SH, Mok JS, Lee JS, An SU, Lee WC (2013) Impacts of long-line aquaculture of Pacific oyster (Crassostera gigas) on sulfate reduction and diffusive nutrient flux in the coastal sediments of Jinhae-Tongyeong, Korea. Mar Pollut Bull 74:187-198

* Jensen MM, Thamdrup B, Rysgaard S, Holmer M, Fossing H (2003) Rates and regulation of microbial iron reduction in sediments of the Baltic-North Sea transition. Biogeochemistry 65:295-317

Jones CM, Ruscoe IM (2000) Assessment of stocking size and density in the production of redclaw crayfish, Cherax quadricarinatus (von Martens) (Decapoda: Parastacidae), cultured under earthen pond conditions. Aquaculture 189:63-71

Jørgensen BB (1978) A comparison of methods for the quantification of bacterial sulfate reduction in coastal marine sediments. 1. Measurement with radiotracer techniques. Geomicrobiol J 1:11-28

Jørgensen BB (2006) Bacteria and marine biogeochemistry. In: Zabel HD, Schulz M (eds) Marine geochemistry. Springer, Berlin, p 169-206

Kim S, Kwon SH, Lee HG, Yu OH (2017) Effects of environmental and biological conditions on the recruitment and growth of the Manila clam Ruditapes philippinarum on the west coast of Korea. Ocean Sci J 52:91-101 (in Korean with English Abstract)

Klinger D, Naylor R (2012) Searching for solutions in aquaculture: charting a sustainable course. Annu Rev Environ Resour 37:247-276

Koh CH, de Jonge VN (2014) Stopping the disastrous embankment of coastal wetlands by implementing effective management principles: Yellow Sea and Korea compared to the European Wadden Sea. Ocean Coast Manage 102:604-621 
Koo BJ, Seo J (2017) Sediment reworking by a polychaete, Perinereis aibuhitensis, in the intertidal sediments of the Gomso Bay, Korea. Ocean Sci J 52:511-518

Kostka JE, Gribsholt B, Petrie E, Dalton D, Skelton H, Kristensen E (2002a) The rates and pathways of carbon oxidation in bioturbated saltmarsh sediments. Limnol Oceanogr 47:230-240

Kostka JE, Roychoudhury A, van Cappellen P (2002b) Rates and controls of anaerobic microbial respiration across spatial and temporal gradients in saltmarsh sediments. Biogeochemistry 60:49-76

Kristensen E (2000) Organic matter diagenesis at the oxic/ anoxic interface in coastal marine sediments, with emphasis on the role of burrowing animals. Hydrobiologia 426:1-24

Kristensen E (2001) Impact of polychaetes (Nereis spp. and Arenicola marina) on carbon biogeochemistry in coastal marine sediments. Geochem Trans 2:92-103

Kristensen E (2008) Mangrove crabs as ecosystem engineers; with emphasis on sediment processes. J Sea Res 59:30-43

Kristensen E, Alongi DM (2006) Control by fiddler crabs (Uca vocans) and plant roots (Avicennia marina) on carbon, iron and sulfur biogeochemistry in mangrove sediment. Limnol Oceanogr 51:1557-1571

Kristensen E, Kostka JE (2005) Macrofaunal burrows and irrigation in marine sediment: microbiological and biogeochemical interactions. In: Kristensen E, Haese RR, Kostka JE (eds) Interaction between macro- and microorganisms in marine sediments. American Geophysical Union, Washington, DC, p 125-157

Kristensen E, Mangion P, Tang M, Flindt MR, Holmer M, Ulomi S (2011) Microbial carbon oxidation rates and pathways in sediments of two Tanzanian mangrove forests. Biogeochemistry 103:143-158

Kristensen E, Penha-Lopes G, Delefosse M, Valdemarsen T, Quintana CO, Banta GT (2012) What is bioturbation? The need for a precise definition for fauna in aquatic sciences. Mar Ecol Prog Ser 446:285-302

Lavoie MF, McKindsey CW, Pearce CM, Archambault P (2016) Influence of intertidal Manila clam Venerupis philippinarum aquaculture on biogeochemical fluxes. Aquacult Environ Interact 8:117-130

Laing I, Utting SD, Kilada RWS (1987) Interactive effect of diet and temperature on the growth of juvenile clams. J Exp Mar Biol Ecol 113:23-28

Lim HS (2016) Growth of the manila clam (Ruditapes philippinarum) cultured in Gomso tidal flat, Korea. Korean J Malacol 32:189-195

Lohrer AM, Thrush SF, Hunt L, Hancock N, Lundquist C (2005) Rapid reworking of subtidal sediments by burrowing spatangoid urchins. J Exp Mar Biol Ecol 321:155-169

* Lovley DR, Phillips EJP (1987) Rapid assay for microbially reducible ferric iron in aquatic sediments. Appl Environ Microbiol 53:1536-1540

*Martinez-Garcia E， Carlsson MS, Sanchez-Jerez P, Sánchez-Lizaso JL, Sanz-Lazaro C, Holmer M (2015) Effect of sediment grain size and bioturbation on decomposition of organic matter from aquaculture. Biogeochemistry 125:133-148

McKindsey CW, Archambault P, Callier MD, Olivier F (2011) Influence of suspended and off-bottom mussel culture on the sea bottom and benthic habitats: a review. Can J Zool 89:622-646

Meliá P, Nizzoli D, Bartoli M, Naldi M, Gatto M, Viaroli P (2003) Assessing the potential impact of clam rearing in dystrophic lagoons: an integrated oxygen balance. Chem Ecol 19:129-146

*Melton ED, Swanner ED, Behrens S, Schmidt S, Kappler A (2014) The interplay of microbially mediated and abiotic reactions in the biogeochemical Fe cycle. Nat Rev Microbiol 12:797-808

*Nam KW, Jeung HD, Song JH, Park KA, Choi KS, Park KI (2018) High parasite burden increases the surfacing and mortality of the Manila clam (Ruditapes philippinarum) in intertidal sand mudflats on the west coast of Korea during hot summer. Parasit Vectors 11:42

* Natálio LF, Pardo JCF, Machado GBO, Fortuna MD, Gallo DG, Costa TM (2017) Potential effect of fiddler crabs on organic matter distribution: a combined laboratory and field experimental approach. Estuar Coast Shelf Sci 184:158-165

Nedwell RIE (2004) Ecosystem influences of natural and cultivated populations of suspension-feeding bivalve molluscs: a review. J Shellfish Res 23:51-61

Nielsen OI, Kristensen E, Macintosh DJ (2003) Impact of fiddler crabs (Uca spp.) on rates and pathways of benthic mineralization in deposited mangrove shrimp pond waste. J Exp Mar Biol Ecol 289:59-81

Nizzoli D, Bartoli M, Viaroli P (2006a) Nitrogen and phosphorous budgets during a farming cycle of the Manila clam Ruditapes philippinarum: an in situ experiment. Aquaculture 261:98-108

Nizzoli D, Welsh DT, Fano EA, Viaroli P (2006b) Impacts of clam and mussel farming on benthic metabolism and nitrogen cycling, with emphasis on nitrate reduction pathways. Mar Ecol Prog Ser 315:151-165

Parsons TR, Maita Y, Lalli CM (1984) A manual of chemical and biological methods for seawater analysis. Pergamon Press, Oxford

*Phillips EJP, Lovley DR (1987) Determination of Fe(III) and $\mathrm{Fe}(\mathrm{II})$ in oxalate extracts of sediment. Soil Sci Soc Am J 51:938-941

* Poulton SW, Canfield DE (2005) Development of a sequential extraction procedure for iron: implications for iron partitioning in continentally derived particulates. Chem Geol 214:209-221

* Powilleit M, Forster S (2018) Continuous and high transport of particles and solutes by benthos in coastal eutrophic sediments of the Pomeranian Bay. Front Mar Sci 5:472

Pyzik AE, Sommer SE (1981) Sedimentary iron monosulfide: kinetics and mechanisms of formation. Geochim Cosmochim Acta 45:687-698

Quintana CO, Kristensen E, Valdemarsen T (2013) Impact of the invasive polychaete Marenzelleria viridis on the biogeochemistry of sandy marine sediments. Biogeochemistry 115:95-109

* Quintana CO, Shimabukuri M, Pereira CO, Alves BGR and others (2015) Carbon mineralization pathways and bioturbation in coastal Brazilian sediments. Sci Rep 5:16122

Rasmussen H, Jørgensen BB (1992) Microelectrode studies of seasonal oxygen uptake in a coastal sediment: role of molecular diffusion. Mar Ecol Prog Ser 81:289-303

Rheault RB, Rice MA (1995) Transient gear shellfish aquaculture. World Aquacult 26:26-31

* Riisgård HU (1988) Efficiency of particle retention and filtration rate in 6 species of Northeast American bivalves. Mar Ecol Prog Ser 45:217-223

* Riisgård HU, Lüskow F, Pleissner D, Lundgreen K, López MÁP (2013) Effect of salinity on filtration rates of mussels Mytilus edulis with special emphasis on dwarfed mussels 
from the low-saline central Baltic Sea. Helgol Mar Res 67:591-598

Roden EE, Wetzel RG (2002) Kinetics of microbial Fe(III) oxide reduction in freshwater wetland sediments Limnol Oceanogr 47:198-211

Sheen SS (2000) Dietary cholesterol requirement of juvenile mud crab Scylla serrata. Aquaculture 189:277-285

Stookey LL (1970) Ferrozine - a new spectrophotometric reagent for iron. Anal Chem 42:779-781

Tang M, Kristensen E (2007) Impact of microphytobenthos and macroinfauna on temporal variation of benthic metabolism in shallow coastal sediments. J Exp Mar Biol Ecol 349:99-112

Thamdrup B (2000) Bacterial manganese and iron reduction in aquatic sediments. Adv Microb Ecol 16:41-84

Thamdrup B, Canfield DE (1996) Pathways of carbon oxidation in continental margin sediments off central Chile. Limnol Oceanogr 41:1629-1650

Thamdrup B, Fossing H, Jørgensen BB (1994) Manganese, iron, and sulfur cycling in a coastal marine sediment, Aarhus Bay, Denmark. Geochim Cosmochim Acta 58: 5115-5129

Timmermann K, Banta ST, Glud RN (2006) Linking Arenicola marina irrigation behavior to oxygen transport and dynamics in sandy sediments. J Mar Res 64: 915-938

*van de Velde S, Meysman FJR (2016) The influence of bioturbation on iron and sulphur cycling in marine sediments: a model analysis. Aquat Geochem 22:469-504

V Varela M, Prego R, Pazos Y (2004) Vertical biogenic particle flux in a western Galician ria (NW Iberian Peninsula). Mar Ecol Prog Ser 269:17-32

Verspecht A, Vanhonacker F, Verbeke W, Zoons J, Van
Huylenbroeck G (2011) Economic impact of decreasing stocking densities in broiler production in Belgium. Poult Sci 90:1844-1851

Welsh DT (2003) It's a dirty job but someone has to do it: the role of marine benthic macrofauna in organic matter turnover and nutrient recycling to the water column. J Chem Ecol 19:321-342

W Welsh DT, Nizzoli D, Fano EA, Viaroli P (2015) Direct contribution of clams (Ruditapes philippinarum) to benthic fluxes, nitrification, denitrification and nitrous oxide emission in a farmed sediment. Estuar Coast Shelf Sci 154:84-93

*Wendelboe K, Egelund JT, Flindt MR, Valdermarsen T (2013) Impact of lugworms (Arenicola marina) on mobilization and transport of fine particles and organic matter in marine sediments. J Sea Res 76:31-38

*Wilber DH, Wilber TP (1991) Environmental influences on the growth and survival of West Indian spider crabs Mithrax spinosisimus (Lamarck) in culture. J Exp Mar Biol Ecol 146:27-38

*Wu RSS, Lam KS, Mackay DW, Lau TC, Yam V (1994) Impact of marine fish farming on water quality and bottom sediment: a case study in the sub-tropical environment. Mar Environ Res 38:115-145

* Zhang A, Yuan X, Hou W, Wang L (2013) Carbon, nitrogen, and phosphorus budgets of the surfclam Mactra veneriformis (Reeve) based on a field study in the Shuangtaizi estuary, Bohai Sea of China. J Shellfish Res 32:275-284

Zhou Y, Yang H, Zhang T, Liu S and others (2006) Influence of filtering and biodeposition by the cultured scallop Chlamys farreri on benthic-pelagic coupling in a eutrophic bay in China. Mar Ecol Prog Ser 317:127-141

Appendix.

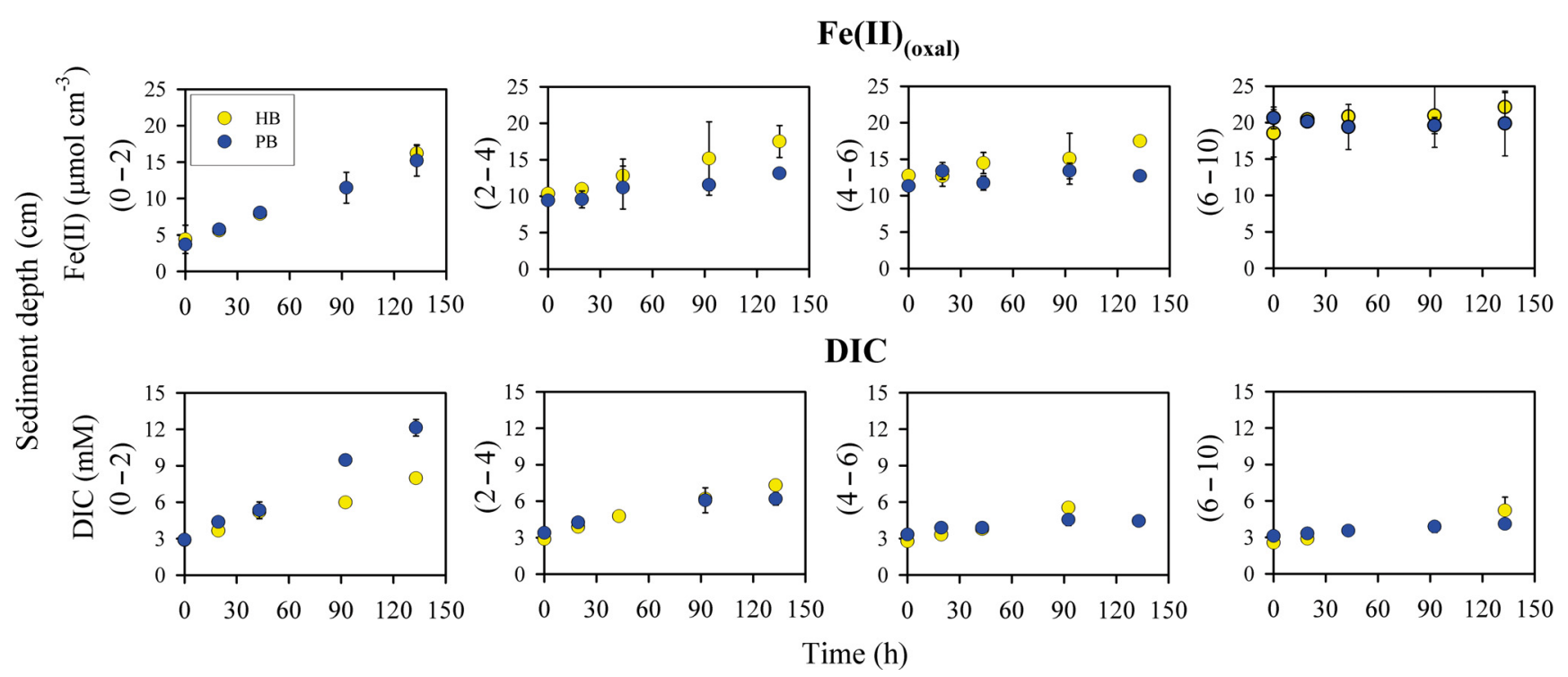

Fig. A1. Changes in Fe(II) $)_{\text {(oxal) }}$ content in the sediment and changes in DIC concentrations in pore water during anoxic incubation of sediment at depths of $0-2,2-4,4-6$, and 6-10 $\mathrm{cm}$ at highly bioturbated (HB) and poorly bioturbated (PB) sites. Vertical bars indicate SE 